1 ] $\mathrm{R}$ S International Journal of Technical Research \& Science

\title{
FUZZY LOGIC CONTROLLER BASED D- STATCOM FOR POWER QUALITY SOLUTION IN DISTRIBUTED GENERATED SYSTEM
}

\author{
Prerna Tundwal, R.R. Joshi \\ E-Mail Id: sainiprerna.97@gmail.com
}

Department of Electrical Engineering, College of Technology and Engineering, Udaipur, Rajasthan, India

\begin{abstract}
Power quality solution in Distributed Generation (DG) Environment is based on non-conventional sources such as solar, hydro, wind, biomass, or bio-fuel. In a distributed system, the deviation between voltage and frequency occurs due to the discontinuous generation of electricity through renewable sources. In this paper intelligent controller as fuzzy controller is used for power quality solution such as voltage sags, swell, interruption, unbalanced load/ power and total harmonic distortion in the system. It includes the pulse width modulation (PWM) controller which is used in VSI. The distributed static compensator (DSTATCOM) is used to mitigate the current based problem and regulate the voltage either by generating or absorbing reactive power. The simulation are performed for all control strategy by using MATLAB/Simulink.
\end{abstract}

Keywords: Distributed Static Compensator, Power Quality, Fuzzy logic, Distributed Generation (DG) Environment.

\section{INTRODUCTION}

The world population is growing naturally so the electricity demand is increased day by day. To overcome their demand it becomes an important issue. Globally, renewable sources are in big trend for energy generation and it is not exhausted by their use, it is naturally like that. The effect of power quality issues is frequently felt by consumers, industrial, commercial, and even residual. Custom power devices, one may assign to power electronics static controllers utilized for power quality enhancement on the distribution system by $1 \mathrm{kV}$ through $38 \mathrm{kV}$. As compared to conventional sources It does less harm to the environment. A growth of 1\% of GDP manages to a $1.4 \%$ increase in electricity requirement in a developing country.

Distributed generation is the latest trend to satisfied the increased electricity demand in power systems. The DG rating depends on voltage levels, local energy sources, and power transfer capability of electrical infrastructure. The development in DG decreases the dependency on the thermal power plant and emission of $\mathrm{CO}_{2}$. The utility cost can be minimized by excluding the necessity for investment. The DG association performs a significant role to satisfied the electricity demand in peak hours, and stability of accelerating voltage. The conventional system gets a longer time and complexity in the process. And fuzzy logic presents the DG optimal location in a short time for any bus.

The Versatile methods are implemented for the constant requirement of safe, reliable, and quality of electricity supply. But two technical challenges are obtained here. First, The increasing difficulty with the environment and conventional fossil fuel so renewable energy source is used. Secondary, The interfacing between load, renewable energy sources, and grid, a custom power device (STATCOM) is used.

\subsection{Distributed Generation}

The distributed arrangement is usually connected to a small-scale generation that is described by DG. The renewable source generates electricity in DC form which is converted into constant DC bus voltage by applying a DC-DC converter. DG represent as generation of electricity within the consumer side or distribution network that is physically distributed. The DG is bidirectional so power flow from the grid to the load. If distributed networks generate power such as PV system, fuel cell, and wind energy so the power can flow back to the grid. The PV system generates electricity in DC form that is directly converted into AC by a DC-AC converter. The distributed generator is provided an excellent voltage profile with suitable energy resources.

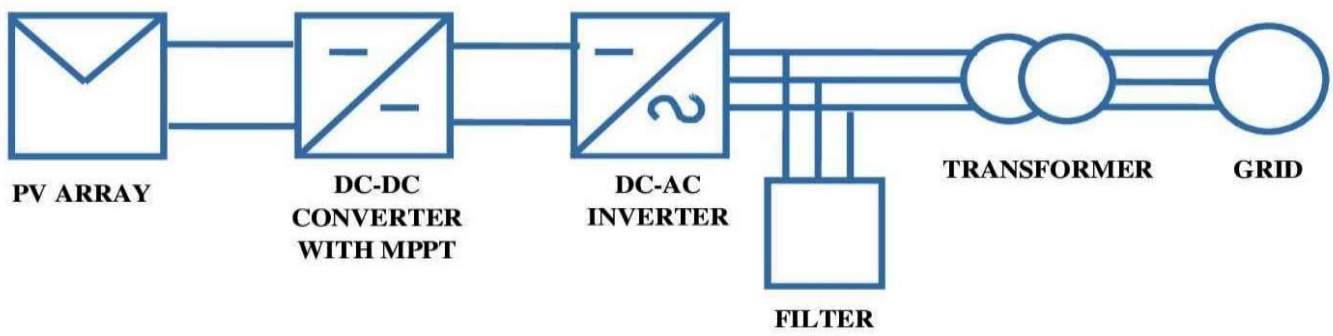

Fig. 1.1 Block Diagram Representation of PV

DOI Number: https://doi.org/10.30780/IJTRS.V06.I07.001 


\section{I] $\mathrm{R}$ S International Journal of Technical Research \& Science}

When we use power electronics interface in renewable energy source so the requirement of extra converter and conditioning equipment of power arises. That causes some disadvantages in the system such as increased costs, a bulkier system, and high switching loss. Therefore the introduced system replaces the requirement for an extra converter with a STATCOM.

Certainly, solar generates electricity during a sunny day only. If daylight is not bright, they don't generate electricity and remain idle. The solar cells with battery energy storage are connected with STATCOM during day and night for higher utilization with cost-effective factors.

The controller is introduced for improvement of power factor or reactive power compensation for STATCOM based on an intelligent controller. The solar cell with battery energy storage also provides support in real power.

\subsection{D-STATCOM}

Custom power devices are used to mitigate the power quality problem in the distributed system. Distributed Static Compensator (DSTATCOM) is a shunt-connected device that is used to regulate voltage either by generating or absorbing reactive power. It can compensate the bus voltage and line current. DSTATCOM is used to mitigate the current based power quality problems such as harmonics, unbalance power/load, reactive power, poor voltage regulator with the help of converters (VSC \& CSI), microcontroller, sensors, etc. For voltage profile improvement and stabilization we can also used advanced static VAR generators.

In DSTATCOM VSC is convert the input voltage of DC into output voltage of three-phase at the fundamental frequency. The reference current of DSTATCOM is managed by evaluating the reference current. By operating, PWM (fixed frequency) or hysteresis (carrier less PWM) current can generate gating pulse over sensed and reference current, result in indirect current control.

The DSTATCOM presents elimination of harmonic currents, reduction in voltage flicker, frequency/voltage regulation, compensator, or fast control of active and reactive power.

The DC supply for the STATCOM device contains a hybrid of triple source (Solar cells, Battery Energy storage and Grid) in the proposed compensation system, and the operation mechanism of the STATCOM with these sources as follows:

When the energy production of solar cells is higher than the compensation power that required by the power system; in this case the excess energy is stored in the battery.

$>$ When the energy production of solar cells is less than the compensation power that required by the power system such as weather is cloudy or at night, in this case the battery compensate for the need of the system partially or completely.

$>$ When the solar cells and battery are inability to provide the system with compensation power required the grid will replace them. And measuring the amount current and voltage from grid or battery or PV to draw the necessary curves in order to show the processing of the solar cell and the battery how much it would cost if the equipment was from the network.

The coordination of all these source and prevent an interference among them is implemented by using a controller.

\section{SYSTEM MODELING AND SIMULATION}

Distributed power generation is connected with STATCOM controller with PWM inverter to minimize the disturbance. We have practiced the solar power of a single-phase grid as a source of formation.

Calculation of DC voltage $\mathrm{V}_{\mathrm{dc}}=\frac{\sqrt[2]{2} \mathrm{~V}_{\mathrm{L}-\mathrm{L}}}{\sqrt{3} \mathrm{~m}}$

Selection of DC capacitor $\frac{1}{2} C_{d c}\left[V_{d c}^{2}-V_{d c 1}^{2}\right]=3 k_{1} V_{p} \alpha I t_{s}$

Selection of interfacing inductor $\mathrm{L}_{\mathrm{f}}=\frac{\sqrt{3} \mathrm{~m} \mathrm{~V}_{\mathrm{dc}}}{12 \alpha \mathrm{f}_{\mathrm{s}} \mathrm{I}_{\mathrm{cr} . \mathrm{P}-\mathrm{P}}}$

Selection of RC filter $\mathrm{R}_{\mathrm{f}} \mathrm{C}_{\mathrm{f}}=\mathrm{T}_{\mathrm{s}} / 10=1 / 10 \mathrm{f}_{\mathrm{s}}$

Table-2.1 Design Parameters of Proposed Work

\begin{tabular}{|l|l|l|}
\hline S. No. & Parameters & Ratings \\
\hline 1. & Grid Voltage & $3-$ phase, $417 \mathrm{v}, 50 \mathrm{~Hz}$ \\
\hline 2. & Induction Motor/ Generator & $4.35 \mathrm{KVA}, 417 \mathrm{~V}, 50 \mathrm{~Hz}$ \\
\hline 3. & Line Series Inductance & $0.07 \mathrm{mH}$ \\
\hline 4. & Inverter Parameter & $\begin{array}{l}\text { DC link voltage }=820 \mathrm{~V}, \\
\text { DC parameter }=210 \mathrm{~F}, \\
\text { Switching Frequency }=1.5 \mathrm{KHz}\end{array}$ \\
\hline 5. & IGBT Ratings & $\begin{array}{l}\text { Collector Voltage }=1250 \mathrm{~V} \\
\text { Forward Voltage }=60 \mathrm{~A} \\
\text { Gate Voltage }=10 \mathrm{~V} \\
\text { Power Dissipation }=300 \mathrm{~W}\end{array}$ \\
\hline 6. & Lon-Linear Load 21KW \\
\hline
\end{tabular}

DOI Number: https://doi.org/10.30780/IJTRS.V06.I07.001

pg. 2

Paper Id: IJTRS-V6-I7-001

www.ijtrs.com, www.ijtrs.org 


\subsection{Fuzzy Logic}

Lotfi A. Zadeh proposed in 1965 a multivalued logic popularly known as fuzzy logic. A fuzzy system is also one of the key agents of computational intelligence. It differs from conventional computing. It involves soft or partial truth/Partial false and deals with uncertainties due to ambiguity, imprecision, randomness, approximation, and vagueness. It is used in multidisciplinary areas. It is much more common than traditional logic systems. Fuzzy logic implements support for the evolution of new tools for natural language processing like computing with words etc. If it increases complexity in a system it will become more challenging and eventually difficult to present a welldefined statement about its performance. The complexity is reaching at a point where the fuzzy method is the only way to perceive the problem. L.A. Zadeh claimed that many sets in the world surrounded by us are defined by a nondistinct boundary.

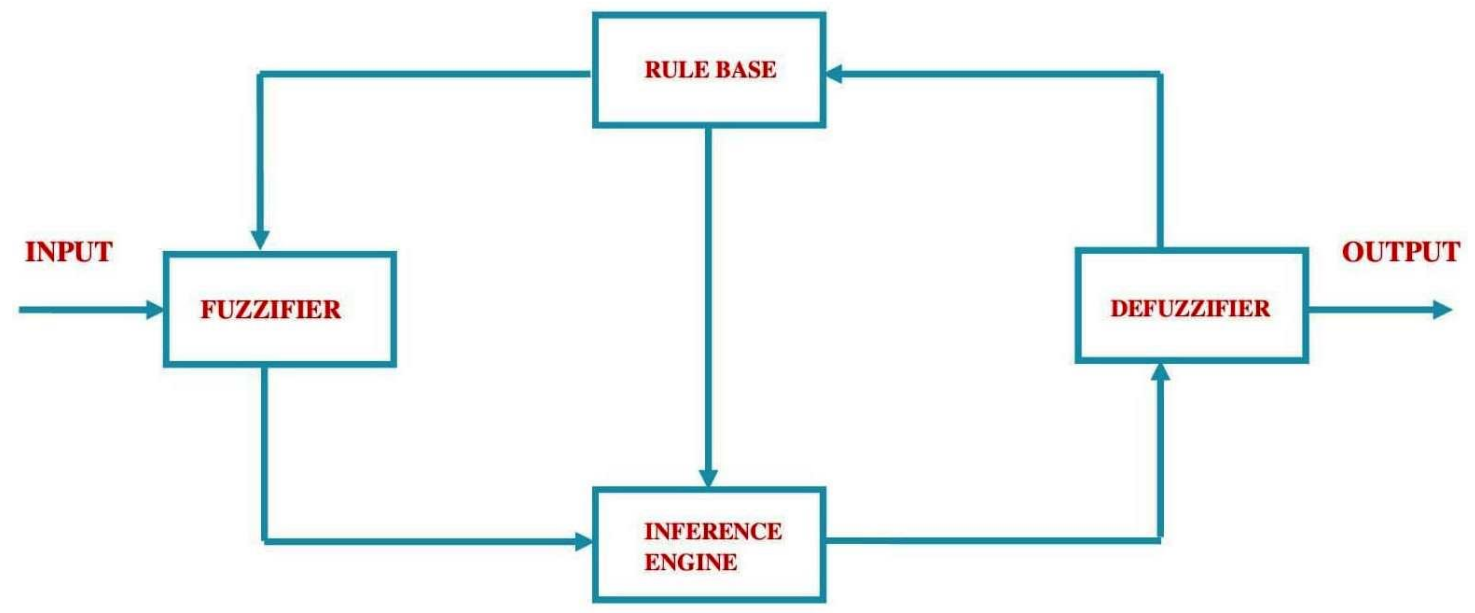

Fig. 2.1 Fuzzy Logic Architecture

\subsection{Fuzzification}

Fuzzy logic is used to convert the crisp value(Numerical variable) into the fuzzy value (linguistic variable). It is based on a knowledge-based membership function to explain the input variable into the fuzzy variable. It does not use numerical variables. The error between output signal and reference signal is consigned as Negative small (NS), Negative big (NB), Negative medium (NM), Zero, Positive small (PS), Positive big (PB), Positive medium (PM). The membership function of triangular is utilized for fuzzification. The control system is used sensors to control the pressure, temperature, RMS, and frequency of the machine.

\subsection{Fuzzy Interference}

Fuzzy interference process mapping from the provided input to output through fuzzy logic. Fuzzy set (if-then rule) and fuzzy reasoning provide a mapping of nonlinear output. The mapping range and domain would be fuzzy sets or points in multidimensional spaces. The fuzzy interference system is successfully implemented in various field such as automatic control, data classification, decision analysis, expert systems, computer vision, etc. Because of its multidisciplinary nature, fuzzy inference system is also known as Fuzzy rule based system, Fuzzy associate memory, Fuzzy expert system, Fuzzy logic controller, Fuzzy model, and Fuzzy system.

\subsection{Defuzzification}

It is used to convert the fuzzy value (linguistic value) into the crisp value (Numerical value) from mathematical calculation. It is used various defuzzification methods which have minimum error and easily fit in the system. For the best result, the output membership function is compared with different process cycle from the best significant point.

Table- 2.2 Rule Based for Fuzzy Logic Controller

\begin{tabular}{|c|c|c|c|c|c|c|}
\hline$\Delta \mathrm{V}_{\mathrm{PV} *}[\mathrm{o} / \mathrm{p}]$ & \multicolumn{6}{|c|}{$\Delta \mathrm{V}_{\mathrm{PV} *}[\mathrm{i} / \mathrm{p}]$} \\
\hline \multirow{6}{*}{$\Delta \mathrm{P}_{\mathrm{PV} *}[\mathrm{i} / \mathrm{p}]$} & & NB & NS & ZE & PS & PB \\
\hline & NB & PS & PB & NB & NB & NS \\
\hline & NS & PS & PS & NS & NS & NS \\
\hline & ZE & $\mathrm{ZE}$ & $\mathrm{ZE}$ & $\mathrm{ZE}$ & $\mathrm{ZE}$ & $\mathrm{ZE}$ \\
\hline & PS & NS & NS & PS & PS & PS \\
\hline & PB & NS & NB & PB & PB & PS \\
\hline
\end{tabular}

DOI Number: https://doi.org/10.30780/IJTRS.V06.I07.001 


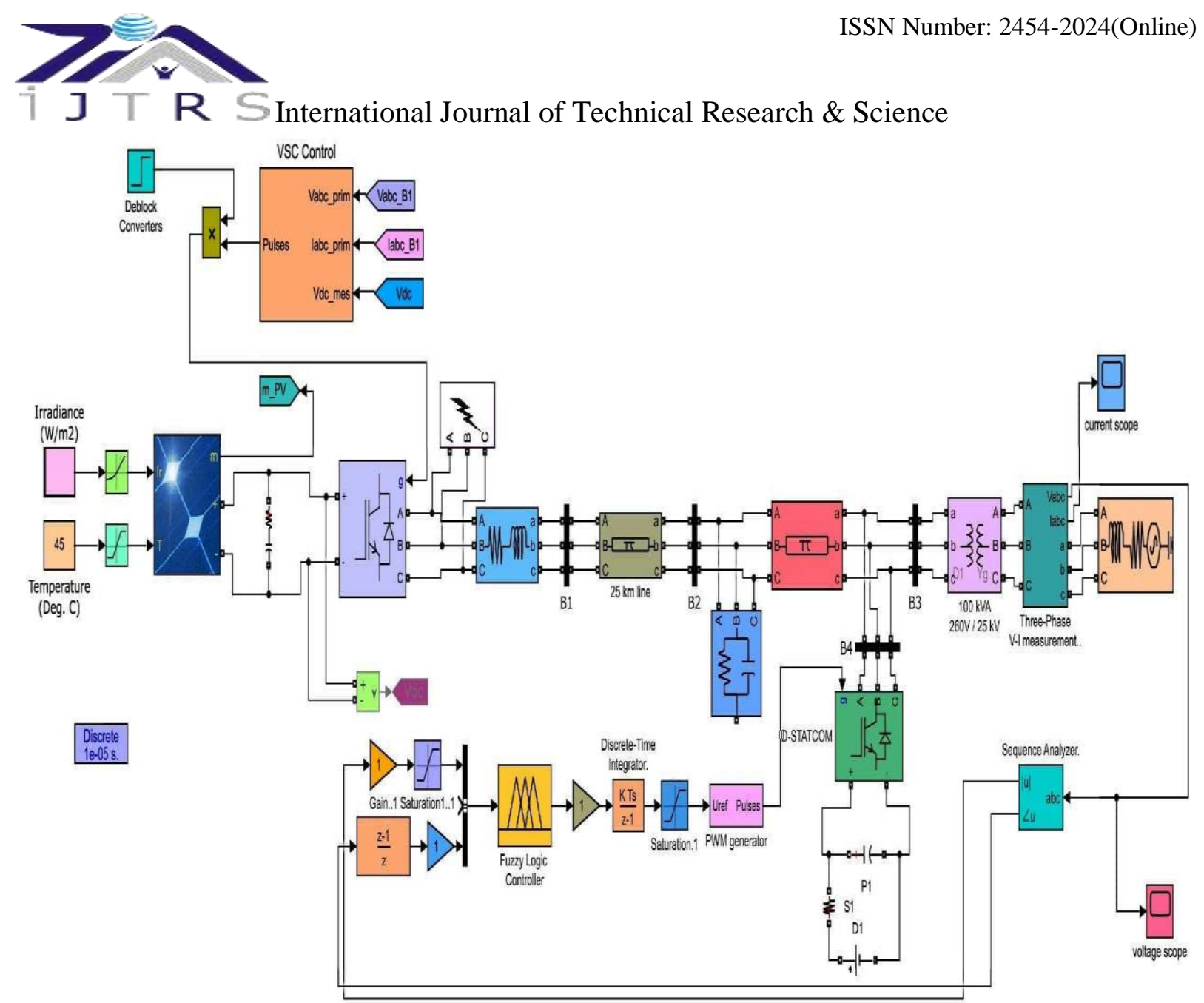

Fig. 2.2 Fuzzy Based PV-DSTATCOM Model

\section{SIMULATION RESULT}

3-phase fault is design for power quality mitigation. Since the duration of fault depends on fault resistance therefore, several fault resistance are created. This case contain line current waveform, DC voltage waveform, power quality waveform and Total Harmonic Distortion (THD) of the line voltage. In system the load parameter are considered as $\mathrm{R}=0.35 \Omega$ and $\mathrm{L}=0.56 \mathrm{H}$. PV based D-STATCOM of $21 \mathrm{kV}$ energy is review as under:

A 3-phase faults are created at point $\mathrm{P}$ via resistance of $0.50 \Omega$ for the transmission time of $0.3 \mathrm{~s}-0.4 \mathrm{~s}$ and system is operated without DSTATCOM, which cause $30 \%$ voltage sag. When system is connected to DSTATCOM, Voltage sags improve to $3 \%$. THD of load voltage improves up to $1 \%$.

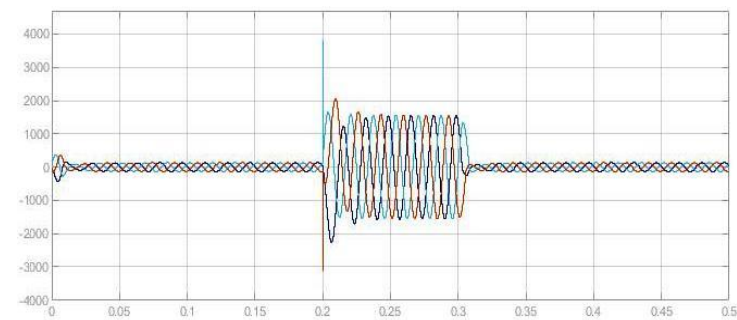

Current without DSTATCOM

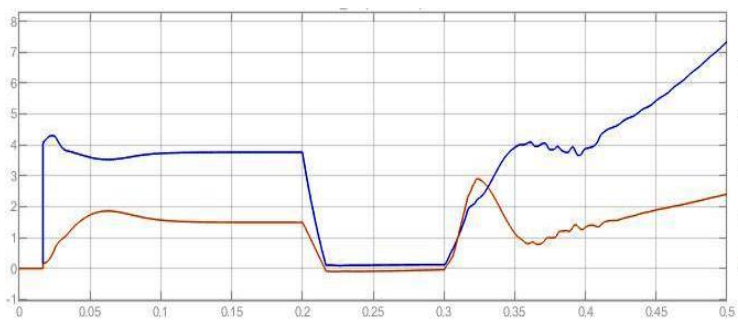

Power Quality without DSTATCOM

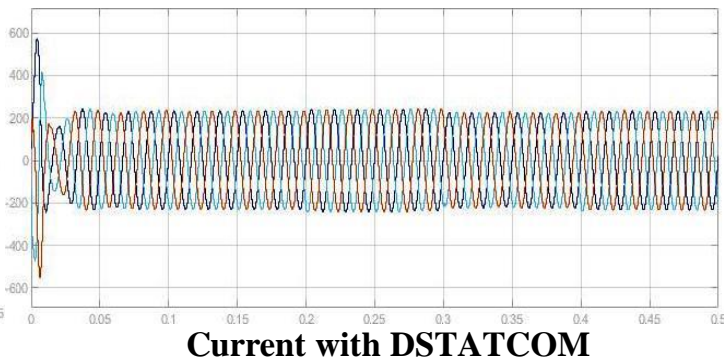

Current with DSTATCOM

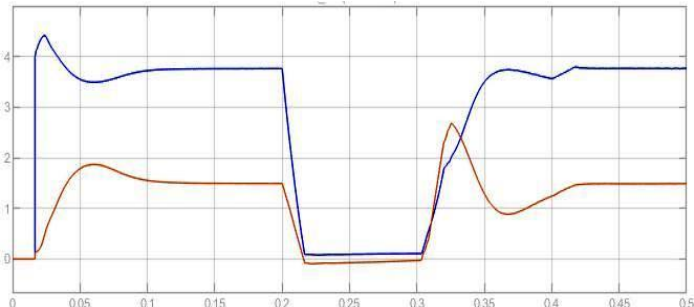

Power Quality with DSTATCOM 
† J T R S International Journal of Technical Research \& Science

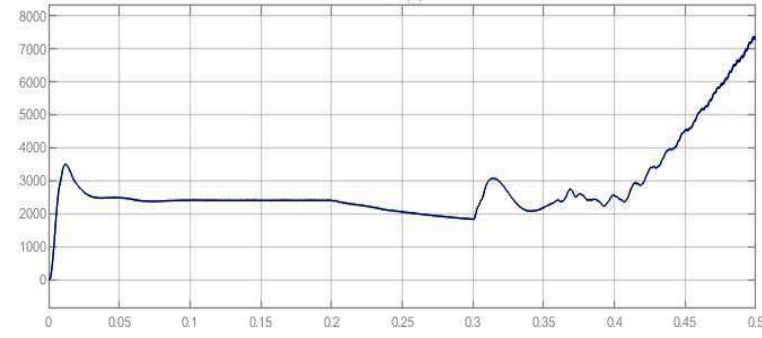

DC Voltage without DSTATCOM

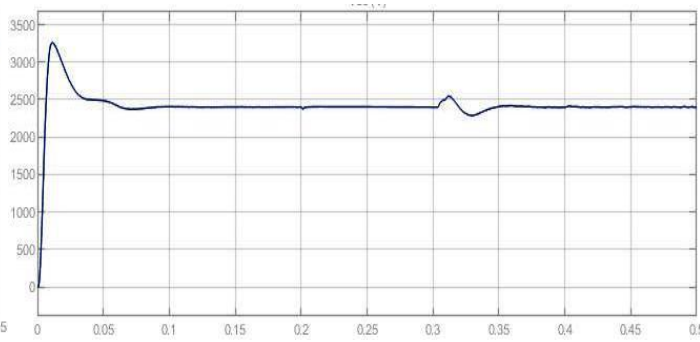

DC Voltage with DSTATCOM
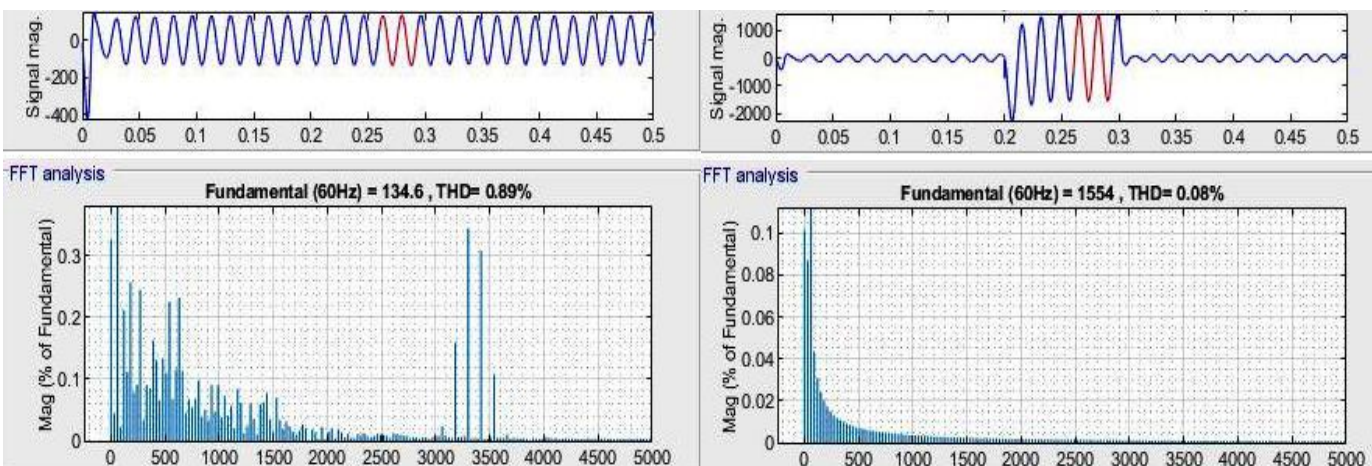

THD of load voltage without DSTATCOM

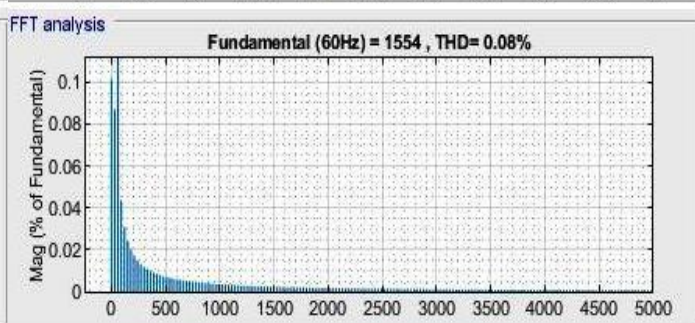

Fig. 3.1 Simulation Result

\section{CONCLUSION}

From the result, we observe that voltage and current deviation occurs on the grid due to nonlinear loads that affect the output in the system. In D-STATCOM operation, the output voltage of the inverter is affected by load. The point of common coupling device shows the power quality improvement. The harmonics are induced by the inverter which is in higher-order and filtered through inductance or transformers in distribution lines. In three phase to ground fault the voltage sag can mitigate up to $5 \%$ to $20 \%$ and harmonics are distorted up to $2 \%$ to $3 \%$ with a decent efficiency. From 3- $\Phi$ fault case study we can conclude that in distributed system DSTATCOM is magnificent choice for the mitigation of harmonic distortion and voltage interruption in the system. On the load side fuzzy logic controller provide excellence performance in form of improved voltage profile, stability and reliability.

\section{REFERENCE}

[1] Abubakar, A.S., Olaniyan, A.A., Ibrahim, A. and Sulaiman, S.H. 2019. An Improved Analytical Method For Optimal Sizing and Placement of Power Electronic Based Distributed Generation Considering Harmonic Limits. In : IEEE PES/ IAS Power Africa in August 20, 2019, pp. 122-127.

[2] Afshari, A., Karrari, M., Baghaee, H.R. and Gharehpetian, G.B. 2020. Distributed fault-tolerant Voltage / Frequency Synchronization in Autonomous AC Microgrids. In : IEEE Transactions on Power System in February 19, 2020, pp. 3774-37789.

[3] Badal, F. R., Das, P., Sarker, S. K., \& Das, S. K. 2019. A survey on control issues in renewable energy integration and microgrid. In Protection and Control of Modern Power Systems 4 : 1-27.

[4] Eltamaly, A.M., Elghaffar, A.N.A., Sayed, Y., \& Sayed A.E., 2018. Enhancement of Power System Quality using Static Synchronous Compensation (STATCOM). In International journal of mechatronics, Electrical and computer technology (IJMEC) $8: 3966-3974$.

[5] Hossain, E., Tur, M. R., Padmanaban, S., Ay, S., \& Khan, I. 2018. Analysis and Mitigation of Power Quality Issues in Distributed Generation Systems Using Custom Power Devices. IEEE Access.

[6] Mohanty, K.B. and Pati, S. 2016. Fuzzy Logic Controller Based STATCOM for Voltage Profile Improvement in a Microgrid. In : Annual IEEE Systems Conference (SysCon) in April 18, 2016, pp. 1-6.

[7] Pati, S., Mohanty, K.B., Kar, S. K. and Mishra, S. 2016. Voltage and Frequency Control of a Microgrid Using a Fuzzy Logic Controller Based STATCOM Equiped with Energy Storage System. In : International Conference on Circuit, Power and Computing Technologies (ICCPCT) in March 18, 2016, pp. 1-7.

[8] Ranjani, R., Rajan, S.E. and Vengatesh, R.P. 2016. Performance Analysis of Coupled Inductor Active Network Converter for Photovoltaic Energy Harvesting System Using Fuzzy Based MPPT Control Techniques. In : International Conference on Circuit, Power and Computing Technologies (ICCPCT) in March 18, 2016, pp. 18.

[9] Singh, B., Kandpal, M. and Hussain, I. 2016. Control of Grid Tied Smart PV-DSTATCOM System Using an 
$7 \mathrm{~T}$ T S International Journal of Technical Research \& Science

Adaptive Technique. IEEE Transactions on Smart Grid 9: 3986-3993.

[10] Singh, K., Sharma, G., Baheti, R. and Singh, A.K. 2020. Allocation of Distributed Energy Resources in Deregulated Electric Power System. In : IEEE 9th Power India International Conference (PIICON),2020, pp. 16.

[11] Verma, A.K., Singh, B. and Shahani, D.T. 2012. Fuzzy Logic Based MPPT Control of Grid Interfaced PV Generating System With Improved Power Quality. In : IEEE Fifth Power India Conference in December 19, 2012, pp. 1-6.

[12] Wu, S., Dang, G., Wang, J., Li, X., Zhang, Z., \& Jiang, F. 2012. Harmonic Control Based on Fuzzy Logic. Physics Procedia, 24 : 1292-1297. 